\title{
THREADS OF A HASHTAG: ENTEXTUALIZATION OF RESISTANCE IN THE FACE OF POLITICAL AND SANITARY CHALLENGES IN BRAZIL
}

\section{FIOS DE UMA HASHTAG: ENTEXTUALIZAÇÃO DE RESISTÊNCIA FACE A DESAFIOS POLÍTICOS E SANITÁRIOS NO BRASIL}

\author{
Marilda C. Cavalcanti* \\ Ana Cecília Cossi Bizon ${ }^{\star \star}$
}

\begin{abstract}
The scenario for this paper is the combined sanitary and political crisis that Brazil has been facing in these unprecedented times of the COVID-19 pandemic. The country is ideologically polarized and this polarization has been enhanced in the last year and a half in Bolsonaro's government. A bleak period characterized by a way of governing that Silva (2020) names "pragmatics of chaos" due to denialism (even of the very pandemic) and to the neoliberal values cherished by a radical right-wing that supports the President and backs the discontinuation of important public policies, mainly those directed towards minoritized groups and environmental protection. Having in mind such a scenario, and amidst the societal bewilderment and inaction regarding the President's contradictory actions towards democracy, we chose to focus on a rare event of direct resistance featured by a migrant of Haitian origin, who told in the face of the president what maybe many Brazilians had not dared to say. What is of interest here is that this performance, recorded on a mobile phone, and posted as a tweet, went viral, and gave rise to a hashtag \#acaboubolsonaro [ItsOverBolsonaro] - that is still alive seven months later. With a focus on the man's performance of resistance and its entextualization on social media, we analyze his discourse and the impacts of his positioning. In the analysis, we try to retrace some of the threads traversed by the hashtag in two Twitter accounts and some of the reverberations on Instagram. We also discuss how the discursive thread of the postings weaves a metareflexive fabric about the man's performance. We see this meta-reflection as an acknowledgment of another praxis that we have called 'pragmatics of resistance'.
\end{abstract}

Keywords: resistance; entextualization; indexicalization; political and sanitary crisis; vulnerable Other.

\footnotetext{
* Universidade Estadual de Campinas, Unicamp, Campinas, SP, Brasil. marilda.cavalcanti@gmail.com Orcid: https://orcid.org/0000-0002-2381-108X

CNPq Fellow (Proc. 311870/2015-5)

** Universidade Estadual de Campinas, Unicamp, Campinas, SP, Brasil. ceciliabizon@gmail.com

Orcid: https://orcid.org/0000-0002-2303-1446
} 


\section{RESUMO}

O cenário para este artigo é a combinada crise sanitária e política que o Brasil vem enfrentando nesses tempos sem precedentes de pandemia de COVID-19. O país está polarizado ideologicamente e essa polarização aumentou no último ano e meio do governo Bolsonaro. Um período sombrio caracterizado por uma forma de governar que Silva (2020) denomina "pragmática do caos" devido ao negacionismo (até mesmo da própria pandemia) e aos valores neoliberais caros a uma direita radical, que apoia o Presidente e defende a descontinuação de políticas públicas importantes, principalmente as voltadas a grupos minoritários e de proteção ambiental. Tendo em vista tal cenário, e em meio ao espanto e à inação da sociedade em relação às ações contraditórias do Presidente no que concerne à democracia, optamos por nos concentrar em um raro evento de resistência direta protagonizado por um migrante de origem haitiana, que disse na cara do Presidente o que talvez muitos brasileiros não tenham ousado dizer. Essa performance, gravada em um celular e postada como um tweet, viralizou, dando origem a uma hashtag - \#acaboubolsonaro [ItsOverBolsonaro] - que continua viva sete meses depois. Focalizando a performance de resistência e sua entextualização nas redes sociais, tentamos reconstituir alguns dos tópicos percorridos pela hashtag em duas contas do Twitter e algumas das reverberações no Instagram. Também discutimos como o fio discursive das postagens delineia um tecido metarreflexivo sobre a performance do Homem. Vemos essa metarreflexão como um reconhecimento de outra práxis, que chamamos de "pragmática da resistência".

Palavras-chave: resistência; entextualização; indexicalização; crise político-sanitária; Outro vulnerável.

\section{INTRODUCTION}

In A cruel pedagogia do vírus [The cruel pedagogy of the virus], Santos (2020, p. 5) situates the global experience of the COVID-19 pandemic as a "normality of exception", i.e. a special state of crisis ingrained in a permanent state of crisis in which great part (if not all) of the global territory has been immersed since the 1980s - a decade that witnessed a progressive strengthening of the contemporary neoliberal dominant strand of capitalism. Closely bound to financial thinking, neoliberalism has been operating to foster the individual and meritocratic constitution of subjects and societies, as it takes away from the State the responsibility for public policies to provide for the basic rights of its citizens, such as education and health.

In the context of an ongoing developmental project across the worldoriented to large-scale production and consumption, we have been witnessing the actions of governments with ultraconservative tendencies. These actions ignore policies regarding the recognition of minorities and/or minoritized majorities from/ in different parts of the world.

This hardened and unilateral thinking that ignores the Other (BHABHA, 2007/1998) results in the maintenance of inequalities and the weakening of less- 
privileged sectors of society. In the case of Brazil, even though basic services are to be provided by the State, health and educational systems are very far from being efficient. In addition to this inefficiency, in the last couple of years, the State has been investing less and less than it should and could in these areas and many of the existing policies have been discontinued. Regarding the area of health, the SUS - Sistema Único de Saúde (the Unified Health System) - has been going through a dismantling process, a threat to its sustainability/viability. Against all odds, the system has been showing vitality in the battle against the coronavirus.

The deterioration of these basic services has directly affected vulnerable groups in the country including recent migrants and refugees. In this regard, it should be pointed out that Brazil has received several waves of displaced people due to what Baeninger and Peres $(2017$, p.122) call "crisis migration", a displacement stemming from financial, political, civil, religious, ideological or humanitarian problems, and having a connotation of "forced migration". These migrants have been potentially even more exposed to the advent of the pandemic (MAGALHÃES et. al., 2020).

In São Paulo, for example, the Casa do Migrante [Migrant House], sponsored by Missão Paz [Peace Mission], an important migration hub in the country, has given support to 4,658 migrants and refugees of 62 nationalities, mainly Haitians, Angolans, Bolivians, Venezuelans, and Congolese, in the first four months of the pandemic. According to Father Parise, one of the Mission's chairpersons, in an interview given to a Brazilian radio station on 26 August 2020, the migrant population first looked for food, sanitization kits, and face masks. In the chairperson's view, there was a general perception of insecurity, failure, and economic retrocession with job losses, and all this generated an overall sense of vulnerability.

In a scenario that saw the combined development of the pandemic with an overall feeling of uncertainty generated by acts of the President of the Republic and his supporters, the national mainstream media soon started reporting several initiatives of solidarity towards vulnerable groups throughout the country. Beyond these collective initiatives, our attention, however, was drawn to the individual agency of a migrant of Haitian origin, referred to in the media and on social media as "the Haitian", but, hereinafter, 'the Man'. He dared to confront the President regarding his position of denial of the pandemic and his presence in anti-democratic acts in the rallies promoted by his supporters. Up until that moment, this new government, having just entered its second year of office, had seen no reactions from a politically polarized Brazilian population. Most of the people in one of these poles seemed to be living in a state of lethargy, partly due to the physical isolation 
during the pandemic, and partly due to the disconcerting disturbances witnessed in the rallies.

With a focus on the Man's performance and the (re)entextualization of his words on social media, this article aims to analyze: (i) how this performance is discursively configured, and (ii) how it impacts virtual collective agency in times of a pandemic. Besides the introduction and the final remarks, the paper is organized into three sections: vulnerable scenarios in the mainstream media, methodological and theoretical threads for analyzing the data, and the data analysis.

\section{THE VULNERABLE SCENARIOS IN THE MAINSTREAM MEDIA: RESISTING A POLITICS OF INDIFFERENCE}

Going back to Santos (2020), among the various lessons learned from the pandemic, one of the most significant and, certainly, of most relevance to our discussion, is the acknowledgment of collective action as a way to strengthen social practices based on solidarity. In his reflection, Santos (2020, p.7-8) underscores the importance of "imagin[ing] democratic solutions based on participatory democracies on the level of neighborhoods and communities". In agreement with the author, we would like to add that, in our view, collective action should be seen as a way to confront what is disregarded in terms of public policies. In other words, it may be a mechanism to resist what we name as 'politics of indifference' regarding the care for the Other. As to solidarity, we adopt Santos' perspective that it is not restricted to virtuous, individualized, and sporadic actions. We also assume with Andreotti (2018, p. 65) that solidarity should be seen as an "ontological project", configuring itself as an "ethical imperative regarding the Other that precedes someone's will: something that does not depend on choice or rational agency". It is a movement of encounter that implies acknowledging oneself "as part of the Other and also as part of a bigger metabolism".

The socio-historical moment that composes the scenario for this study in Brazil, with an ongoing pandemic and with governmental contradictions, has exposed the entrails of socioeconomic differences and frailties and also the abyssal line (SANTOS, 2002) between the rich and the poor. It is in this scenario that 'collective solidarity as resistance' strongly emerges - notably that solidarity that happens within inter-and intra-vulnerable groups. However, even stressing the importance of collective resistance that moves through "ontological" solidarity, we also legitimize 'individual resistance' as an important way to grab or to grant agency to discursive bodies. It is against this background and within this perspective that 
we look, in this section, at the way that the media represents vulnerable groups, with special attention to migrants.

At the very beginning of the pandemic, migrants were ignored in the media, but soon the focus of mainstream newspapers turned to vulnerable groups in lowincome communities. News about actions of social solidarity towards these groups became recurrent, but what called our attention was that there was a great deal of intragroup solidarity as, for example, in the case of Paraisópolis, the biggest low-income community in the city of São Paulo. Paraisópolis made the headlines of mainstream media nationally and internationally as a model of organization, monitoring of virus spread, and low level of lethality. In other pieces of news, we also spotted not only intragroup but also intergroup solidarity when migrants from different nationalities were shown handing out face masks, made by migrants' collectivities, to the population of Paraisópolis. We have then realized that there existed several migrant support and solidarity networks run by Brazilians, but there were also migrants engaged in different social sectors, who actively participated in collective actions of solidarity and inclusion. These ongoing solidarity initiatives and projects took us by surprise in a positive way.

In the wake of these pieces of news, there was an instance of resistance displayed by an indigenous collectivity, part of another group neglected by the present government. Feeling the need to fight against the lack of public policies for his people and fearing the arrival of Covid-19 in the villages, Yanama Kuikuro, president of the Associação Indígena Kuikuro do Alto Xingu [the Kuikiro Indigenous Association of High Xingu], launched a virtual campaign. With the funds raised, the association improvised a hospital, contracted a medical doctor and a nurse, and bought PPEs (personal protective equipment), and an air rescue plan for emergency cases. Thus, even though they have recorded a significant number of people infected by the virus, all survived. Unfortunately, not all of the indigenous communities could count on organized horizontal actions such as this one and end up with a higher death rate.

These scenarios of vulnerability and solidarity, which include migrant grassroots movements, highlight intragroup grassroots solutions to governmental problems. All of these actions and solutions have shown promptness, efficiency, organization, and creativity. We see these movements as reactions of resistance to the lack of public policies already mentioned.

Tracing these actions of solidarity as resistance in the media led us to other online news on migrants, and also to social media where we came across an unexpected bewildering event: a video showing a Black man - later identified as a 
migrant of Haitian origin - bluntly telling the President that he was out of his post, that he was spreading the virus, and that he was going to kill his countrymen. The video, posted on YouTube and reposted on Twitter, went viral nationally and gave rise to the hashtag that is the focus of this article.

\section{NOTES ON METHODOLOGY AND ANALYTICAL THREADS STEMMING FROM THE DATA}

The corpus for this paper comes from a set of hybrid data from digital archives, both from mainstream media in the country and also from social media. It resulted from a daily routine of checking the news after the video went viral on social media and also from a repeated digital search on Google, Twitter, and Instagram using the words: baitiano, bolsonaro, acabou bolsonaro, bolsonaro acabou. In this search, two Twitter accounts of public figures and two Instagram accounts of art designers stood out. We tried to establish contact with the account owners' but only had replies from the artists. With these one of the authors of this article held conversations by email. As researchers and also real-time participants in a sociohistorical moment permeated by an unprecedented political, sanitary, and economic crisis in the country, we kept the search routine for seven months (16 March to 16 October 2020). For this article we have chosen a cutout of the corpus corresponding to March-April 2020 and encompassing: (i) the video (with our transcription checked against other transcriptions found in the media); (ii) some posts and replies from two Twitter accounts; (iii) a cartoon published in the Instagram account of an individual artist, and (iv) a virtual poster from the Instagram @acabou_posters.

Watching the video, we soon noticed it had a performance (BAUMAN; BRIGGS, 1990) load regarding the two protagonists. One of the protagonists was a stranger and his performance was unforeseeable. The other - the President - is a very familiar face both nationally and internationally due to his anti-democratic and denialist praxis, described by Silva (2020, p. 507) as "pragmatics of chaos" - "a reflexive, ordered and laminated method of producing a permanent sentiment of agitation, murk, and discontent in political audiences while a conservative and freemarket agenda is radicalized in Brazil". As this agenda is not committed to caring for the Other, we see it as a 'politics of indifference'.

The more we looked at the images, listened to the audio, and worked on the transcription, the more we were convinced that the video also carried a high potential for metapragmatic reflexivity (BLOMMAERT, 2005; BAUMAN, BRIGGS, 1990; GONZALEZ; MOITA LOPES, 2018; RAJAGOPALAN, 2014; 
SIGNORINI, 2008) and, hence, for (re)entextualizations related to the episode and its protagonists. This potential should provide us the raw material for our metareflection and discursive analysis of the reverberations of the episode. In alignment with Bauman and Briggs (1990, p. 73), we take entextualization as

the process of rendering discourse extractable, of making a stretch of linguistic production into a unit - a text - that can be lifted out of its interactional setting. (...) Entextualization may well incorporate aspects of context, such that the resultant text carries elements of its history of use within it.

In this article, the concept of entextualization is relevant " $[t]$ o understand text and discourse as performances [and this] requires that analysts not only pay attention to the intrinsic relation of texts with their contexts" (SILVA, 2014, p. 69). On this path of (re)entextualizations, we pay particular attention to how discursive threads are weaved and intertwined, indexing resistance.

When we act and reflect on our social practices, we activate a series of semiotic resources (including linguistic and paralinguistic choices). Aligned with Blommaert et al. (2015, p, 121), we understand indexicality as "the dimension of meaning in which textual features 'point to' (index) contextually retrievable meanings". In the process of indexicalization, as pointed out by Bizon (2013, p. 104), language choices,

besides being able to flag and [also] to create aspects of context, may also index given voices or social places, since the words we use, inevitably, have already been used by others and end up functioning as an echo both of social places and also of ideological commitments present in our (re)appropriations.

When dealing with indexicalization, Bloomaert (2015, p. 12), furthermore, calls attention to the importance of discursive scalarity as an important tool. We understand scalarity as an analytical resource used to connect different scales of discursive production, always traversed by power relations (CARR, LEMPERT, 2016; GONZALEZ; MOITA-LOPES, 2018). In our data, this resource opens up a productive way to analyze the episode as it travels, transits, and is entextextulized in different SpaceTime impacting social life. According to Gonzalez and Moita Lopes $(2018$, p.16) "the notion of scale makes it possible to analyze how language forges dimensions of social life when establishing perspectives, positionings, comparisons, evaluations, categorizations".

Therefore, in search of piecing together the path tread by the entextualizations of the Man's performance, we analyze discursive moments of agency and resistance 
by making use of some of the "indexical cues" as proposed by Wortham (2001) (see Fig.1) with additions and adaptations by Bizon (2013) (see Fig 2).

Reference and predication: the use of adjectives, nouns, and other expressions to create evaluations and positionings about the referent.

Epistemic modalization: verbal tenses and formulaic expressions that indicate the narrators' more or less epistemic access to the event itself and the narrated event.

Evaluative indexicals: "lexical items, grammatical constructions, accents, and any [of several] other linguistic patterns" (p. 73) associated with particular groups of people.

Metapragmatic descriptors: verbs of enunciation (verbs of saying) used to refer and characterize the way something has been said, voicing narrators' and characters' voices and evaluating them.

Figure 1. Wortham's (2001) Indexical Cues

Citation of authority, an expansion of Wortham's citation cue: reference to a knowledge attributed to an authority extended to a narrator and/or e character in the event.

Reference and predication semiotic cues: paralinguistic indices and prosodic cues and non-verbal indices.

Use of figures of speech: metaphors, comparisons, antitheses, among other language resources that help to voice and position narrators and narrative characters.

Strategic absolutization: Inspired by Spivak's concept of "strategic essentialism", this cue consists of the use of words and expressions to refer to and evaluate situations, actors, etc. as a totalization.

Figure 2. Bizon's (2013) addition to Wortham's Indexical Cues

\section{IT'S OVER, BOLSONARO! AN UNEXPECTED PERFORMANCE?}

The event happened on March 16, 2020, the day after the president had taken part in a rally pro-his-government. In the video, the Man criticizes Bolsonaro's participation in the rally the day before, disrespecting the COVID-19 sanitary rules for physical distancing. Organized by his supporters, the rally, described by the media as an anti-democratic act ${ }^{1}$, had banners, placards, and posters holding offensive words towards the Brazilian Supreme Court and the Congress. It should

1. There is a judicial inquiry on this act in the Brazilian Supreme Court. https://g1.globo.com/ politica/noticia/2020/06/15/entenda-inquerito-do-stf-sobre-manifestacoes-antidemocraticas.ghtml (Accessed 15 June 2020). 
be emphasized that in March, the COVID-19 pandemic had already started in the country, bringing in feelings of fear, doubt, and uncertainty to a quarantined population. The very first death due to COVID was officially reported on March 17.

The three-minute-long video ${ }^{2}$, with no claim of authorship and seemingly recorded on a mobile phone, was made in a fenced area located at the entrance of the presidential palace in Brasília, where the President usually stopped to talk to his supporters. It begins with the President's motorcade arriving at the palace and getting out of one of the cars. He waves to the cheering group waiting for him and addresses them:

1. Presidente: Vocês têm alguma pergunta aí, pessoal?

2. Mulher (levantando a mão): Sim!

3. Homem: Sim, eu tenho pergunta!

4. Apoiadores (gritando): Mito! Mito!

5. Homem: Senhor? (O presidente pede que manifestantes façam silêncio para ele ouvir a pergunta.) Você não recebe mensagens de WhatsApp que seus filhos manda pra você?

6. Presidente: Qual é a sua nacionalidade?

7. Homem: Eu venho do Haiti, eu sou agora brasileiro!

8. Presidente: Pois não!

9. Homem: Eu vim do Haiti, eu sou brasileiro! Presidente, você tem livre escolha, você sabe muito bem, você sabe muito bem que eu fiz minha escolha pra vir de país, pra vir de país...

10. Presidente: Me desculpa, viu, eu não tô entendendo.

11. Homem: Você está entendendo bem! Você está entendendo, eu estou falando brasileiro!

12. Presidente: Não, eu não estou entendendo, não.

13. Homem: Bolsonaro, acabou! Você está recebendo mensagem no celular. Todo brasileiro está recebendo mensagem no seu celular. Você está recebendo mensagem que seus filhos mandaram pra você. Você não é presidente mais! Você não é presidente mais! Você precisa desistir! Você está espalhando vírus e vai matar os brasileiros!

14. Mulher: $\mathrm{O}$ que é isso? O que é isso? (Há um burburinho entre as pessoas presentes. Outras pessoas começam a falar com Bolsonaro e um homem se oferece para fazer uma oração para o presidente.)

15. Presidente: Eu estou trabalhando desde sete da manhã! (Bolsonaro dá as costas para as pessoas no cercadinho e começa a caminhar em direção ao palácio, mas no caminho ele para, se vira para trás - para o cercadinho - e grita para o haitiano:) Volta para seu país, cara! Volta para aquele antro!

2. https://www.youtube.com/watch?v=c664gnwBqGI (Accessed 10 September 2020). 
1. President: Hey you, do you have any questions?

2. Woman (raising her hand): Yes!

3. Man: Yes, I have a question!

4. Supporters (cheering): Myth! Myth!

5. Man: Sir? (Bolsonaro asks his supporters to be silent for him to hear the question.) Haven't you got WhatsApp messages from your sons?

6. President: What's your nationality?

7. Man: I come from Haiti. Now I'm Brazilian!

8. President: Go ahead.

9. Man: I came from Haiti, I am Brazilian! President, you have free will, you know very well that I made my choice to come here from Haiti ...

10. President: Sorry, I don't understand.

11. Man: You do understand! You understand, I'm speaking Brazilian.

12. President: No, I don't understand.

13. Man: Bolsonaro, it's over! You are receiving messages on your mobile phone. Every Brazilian is receiving a message on their mobile phones. You must have received a message from your sons. You are not president anymore! You're not president anymore! You have to give up! You are spreading the virus and you're going to kill the Brazilian people!

14. Woman: What's going on? What's going on? (There is a buzz in the audience. Other people start to talk to Bolsonaro and a man offers to pray for the President.)

15. President: I've been working since 7 a.m.! (Bolsonaro turns his back on the people and starts to walk towards the palace, but on the way, he stops, turns around, and yells at the Haitian man Go back to your country, guy! Go back to that squalor!

It is important to stress that the fenced area only welcomes the President's supporters. It is a place to cheer and praise him and the Press is not usually welcome. Thus, this area may be seen as an artificial scale of life, a perfect world, where he talks to his supporters about his conservative agenda, only allowing questions and replies from those positioned as submissive or as fully compliant with the rules he establishes. However, on the evening of March 16 (2020), there was a stranger in the fenced area, a Black man. His presence does not seem to call attention as he may have been taken for one of the President's supporters. The Man calls for a turn and as it is granted by the President, he places a question: "Haven't you got WhatsApp messages from your sons?" (Turn 5). The question, surprisingly, first brings about no reaction (or maybe inaction) from the President (who is usually rude and aggressive in his answers) and from the audience. Bolsonaro replies with another question: "What's your nationality?" (Turn 6). In the audio, the Man's slight accent indexes that he is a foreigner. Considering the President's aversion regarding an existing 
migratory policy that favors "crisis migrants", and, also, perhaps, the fact that the migrant is Black, the question asked seems to be part of a protocol to allow or not for the presence of this stranger, this foreigner who may certainly be a migrant. The Man's reply to Bolsonaro's question ("I come from Haiti, I am Brazilian!" (Turn 7) may be seen as a clear allusion to his choice of nationality. The man does emphasize this choice in the last part of his reply: "President, you have free will, you know very well that I have made my choice to come here from Haiti." (Turn 9)

At this point in the conversation, there is a change of lead between the interlocutors. The President as a natural leader in this conversation becomes the one who is to be led when he says "I don't understand" (Turn 10). However, the Man insists, in a proactive manner, by using repetitions to contradict the president: "You do understand! You understand, I'm speaking Brazilian" (Turn 11). But Bolsonaro repeats: "No, I don't understand" (Turn 12). And when he says so, it is as if he were saying 'what's going on? what is this about?' (as one of his supporters reacts: see Line20).

The Man grabs the turn again and pours out an announcement (Turn 13) in a very assertive way. The announcement must have caused surprise and astonishment to the President and his supporters for they all remain silent and still as if in a frozen image. With the second, third, and fourth sentences, the Man seems to have a piece of information that nobody in the fenced area does. The Man carries on, saying twice in a row: "You're not president anymore!" (Turn 13) And this is immediately followed by an order: "You have to give up!" (Turn 13) This order is part of a crescendo in the change of roles in the interaction. What was announced in the first sentence as "over" is now unfolded in the use of the imperative, and this may suggest a cry to stop fostering people's agglomerations amid the pandemic. This cry is materialized in the Man's last statement: "You are spreading the virus and you're going to kill the Brazilian people!" (Turn 13). Thus, the announcement made by the Man ends up evaluating the President as someone toxic, positioning him as someone not able to take care of a country.

As to the change of roles in the interaction, it becomes still more evident with the Man's following statements: "I am Brazilian" (Turns 7 and 9)) and "You're not president anymore!" (Turn 13). The use of a figure of speech, an antithesis, in "I am/You're not", and the Man's calm and assertive way make the event not only impacting but also almost surreal, given the courage needed for such an act of resistance.

The most impacting statements addressed to Bolsonaro in the video are Bolsonaro, acabou! Você não é presidente mais! [Bolsonaro, it's over! You're not the 
president anymore (Turn 13)]. These sentences crystallize the Man's protagonism in a performance that indexicalizes resistance and triggers entextualization.

As we show in the next section, the entextualization threads of the Man's performance signal a meta-reflexive process on his praxis, here named 'pragmatics of resistance'. The name was developed in analogy and dialogue with Silva's (2020) "pragmatics of chaos" (see Section 3).

\section{FOLLOWING THE THREADS OF A HASHTAG}

Published in several digital/press media, the video had reverberations on social media, especially on Twitter. On March 17, the day that followed the video publication, the hashtag \#AcabouBolsonaro [\#ItsOverBolsonaro] reached first place in the national trending topics on Twitter ${ }^{3}$, according to information from Blog da Quaest ${ }^{4}$. A national social media analytics agency, Quaest analyzed a sample of 52,489 posts on Twitter from March 8 to 18/2020 in 21,930 accounts. The focus of Quaest's $s^{5}$ analysis was not related to the reverberation of the video but to the several requests for the destitution of the President that had been received by the House of Representatives, including the ones after the antidemocratic rally on March 15. Although not mentioning the video, the blog indicates that the hashtag in focus - \#AcabouBolsonaro - was part of a triad that also included \#ForaBolsonaro [OutBolsonaro], and \#ImpeachmentdoBolsonaroURGENTE [URGENTBolsonarosImpeachment].

Quaest's analysis also indicates that the date of March 17 coincides with pot-bangings in the capital cities of Rio and São Paulo. Before moving to the next section, a word about this type of protest is called for. Pot-bangings ${ }^{6}$, i.e. banging on pots and pans with wooden or metal cutlery, first appeared in political street protests in Chile in 1971. Years later it was similarly used in Argentina (2001). In Brazil, the continued street protests of 2013 had the addition of pot-bangings from windows and balconies of residential vertical condominiums, mainly in big cities throughout the country. During the pandemic, due to the stay-at-home and physical distancing orientation, pot-bangings were adopted in opposition to

3. A response from Bolsonaro's supporters on Twitter came with the hashtag \#RespeiteOPresidente [\#RespectThePresident]. On March 18, this hashtag shared the lead in the trending topics with \#ItsOverBolsonaro. (MARANGONI, 2020, Revista Oeste).

4. http://quaest.com.br/blog/ (Accessed 10 September 2020)

5.http://quaest.com.br/blog/posts/impeachment-bolsonaro-twitter/. (Accessed 2 September 2020).

6. https://www.cartamaior.com.br/?/Editoria/Politica/O-panelaco-e-as-formas-do-protesto-social/4/33657 (Accessed 20 October 2020). 
the anti-democratic rallies that meant crowding on the streets. They were usually combined with the shouting of political slogans and also with the turning on-off lights in the evenings. Sometimes the protests also had laser projections of the hashtag as a political slogan on the façades of vertical buildings.

\section{Pot-bangings for 14 consecutive days}

The first post that we found with a comment about the video was in the Twitter account of the federal congressman Guilherme Boulos, Partido Socialismo e Liberdade (PSOL) [Socialism and Freedom Party]. Boulos, one of the main leftist leaders in the country, was one of the several candidates for the presidency of Brazil in 2018. His tweet (see Boulos' Tweet 1), dated March 17, 2020, 09:55 a.m., reposts the video with the addition of a caption: Bolsonaro acabou!!!! [Bolsonaro is over!!!].

\section{Boulos' Tweet 1}

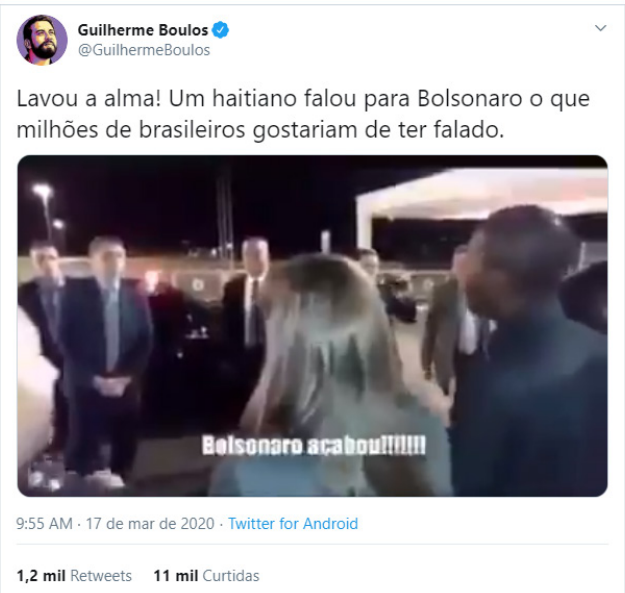

["My soul is redeemed! A Haitian has said to Bolsonaro what millions of Brazilians would like to have said."]

Still, on the same day, Boulos posts a call (see Boulos' Tweet 2) for a potbanging on March 18, 2020, in defense of public health and social protection. The invitation is tagged with \#PovoSemMedo [\#PeopleWithoutFear]. 


\section{Boulos's Tweet 2}

\section{Guilherme Boulos $\theta$ GuilhermeBoulos 17 de mar}

Amanhă! Barulhaço na janela de casa em todo o Brasil. Em defesa do Sus e da proteção socia!! "PovoSemMedo

["Tomorrow! A real big noise at house windows all over Brazil. In defense of SUS and of social protection. \# PovoSemMedo [\#PeopleWithoutFear]"]

Then Boulos posts new invitations for pot-bangings in the format of posters (see Tweets 3 and 4) on March 19 and 21. In Tweet 3, a new tag - \#AcabouBolsonaro [\#ItsOverBolsonaro] - arises and is shared with \# PovoSemMedo. The new tag appears on its own in Tweet 4, and in the invitation posters (in Tweets 3 and 4 ) the hashtag is brought to a central place.

We have not identified who created the hashtag. For us what matters is to show how soon it arises, goes viral, and becomes the main political slogan in a sequence of protests that happen in March and April, when the pandemic is growing and the President is fiddling with the COVID 19 ("it's just a sniffle!") and not following health advice coming from the WHO and also from the Brazilian Ministry of Health.

Boulos' Tweet 3

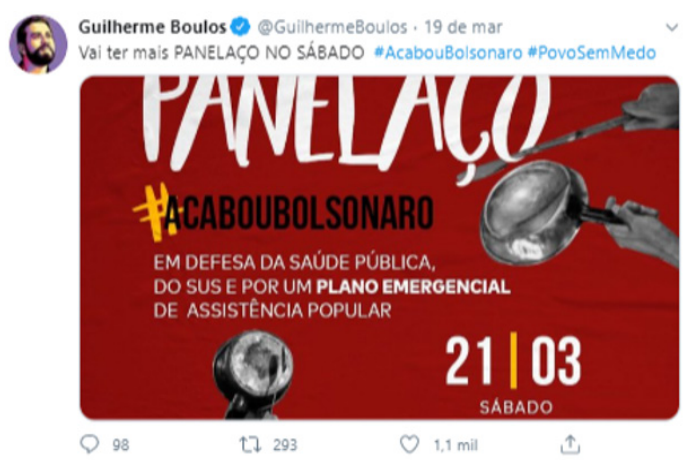




\section{Boulos' Tweet 4}

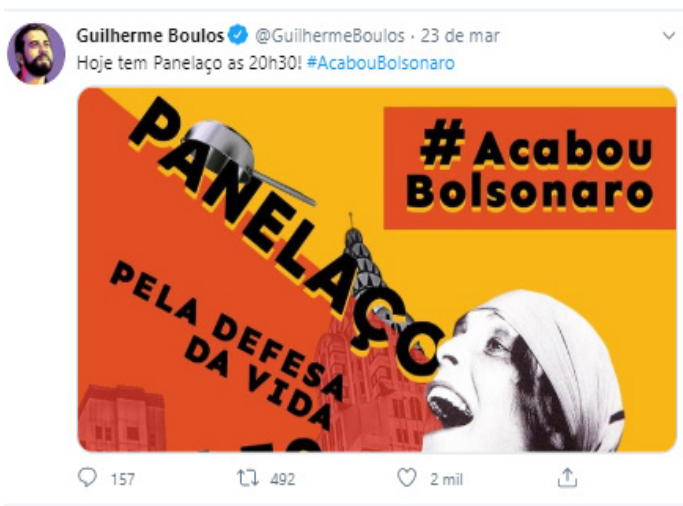

Notice that in Boulos' Tweet 1, the Man's most striking phrase - Bolsonaro Acabou [Bolsonaro is over] -, used as a caption for the video, is entextualized as Acabou Bolsonaro!!! [It's over Bolsonaro!!!]. The change in the word order, in our view, emphasizes the end of the President's government. It is relevant to underscore that both phrases appear as trending hashtags. However, as already pointed out, only one - \#AcabouBolsonaro - reaches first place in the national trending topics on Twitter on March 17. We take both sentences as having a vocative: 'Bolsonaro, it's over!' or 'It's over, Bolsonaro!'

In this same Tweet 1, Boulos voices himself as someone who is represented by the Man. He does so by using the metaphor Lavou a alma! [My soul has been redeemed!]. Furthermore, on a comparative scale, Boulos metonymically projects the Man's words (a part) as the desired words of "millions of Brazilians" (the whole). This projection contributes to a positive evaluation of the Man as a respectable citizen to be in the country. And this contrasts with Bolsonaro's words yelled at the Man at the end of the scene: "Go back to your country, guy! Go back to that squalor!" (Turn 15). Boulos humanizes the Man placing him as a model of courage and good manners - as he knows what and how to speak, whereas the President, exposes lack of manners when he yells at the Man, thus evaluating him negatively in a xenophobic ${ }^{7}$ way.

In Boulos' Tweet 1, the verb "say" - used in "A Haitian has said to Bolsonaro what millions of Brazilians would like to have said" - is a metapragmatic descriptor

\footnotetext{
7. In an interview in 2015, when Bolsonaro was pre-candidate to the presidency of the country, he said that he saw migrants and refugees as the "scum of the world.": https://www.jornalopcao.com. br/ultimas-noticias/bolsonaro-ve-imigrantes-como-ameaca-e-chama-refugiados-de-a-escoria-domundo-46043/ September 18, 2015 (Accessed 13 September 2020).
} 
that signals an action to be taken as a model. Notice that this tweet is an invitation for a barulbaço ${ }^{8}$ [a loud noise, a row] "at house windows all over Brazil". This barulbaço may be interpreted as a call to multiply the Man's words into "thousands of voices". The invitations that follow reaffirm the idea of summoning to action, both by the use of the term "pot-banging" as well as by the mobilization of semiotic resources of reference and predication such as the images of pans (in the first poster) and the image of a young woman with her mouth open as if she were shouting political slogans (in the second poster).

In Boulos' invitations, we see the use of the hashtag \#It's Over Bolsonaro in a scalar progression. In other words, the hashtag is appropriated to reinforce activism of resistance following a path that goes from using the words as a caption (Tweet 1), through transforming the caption into a hashtag and placing it as a shared tag (together with \#PeopleWithoutFear) in Tweet 3. In the same Tweet 3, the hashtag appears again at the center of one of the invitation posters. In Tweet 4, \#itsOverBolsonaro is used as part of another invitation poster and then, for the first time in our data, it is seen as occupying a solo place as a tag for the post. From then on, other scalar progressions may be observed when the hashtag leaves a micro trajectory in a Twitter account and starts to tread other multiscalar trajectories both on Twitter and on other social media as shown in the next section.

\section{A Haitian Giant who came from the Future}

To continue to follow the entextualization path of the episode, we now focus on a tweet by Gregorio Duvivier, a well-known digital influencer, actor, comedian, blogger, and one of the members (and co-creator) of Porta dos Fundos ${ }^{9}$ [Back Door]. At almost the same time as Boulos publishes his first post, Duvivier reposts the video in his Twitter account (see Duvivier's Tweet 1) with two separate posts followed by a long sequence of replies. A few of them were selected for analysis. Both the tweet and replies encapsulate a flux of metapragmatic reflections.

8. The word may be seen as a variation of pot-banging with the shouting of political slogans and the use of other noise-making tools besides pans.

9. A film production company, Porta dos Fundos [Back Door] was the focus of an attack with firebombs by an allegedly Brazilian radical right-wing group on Christmas Eve in 2019. 
Duvivier's Tweet (with 2 separate posts)

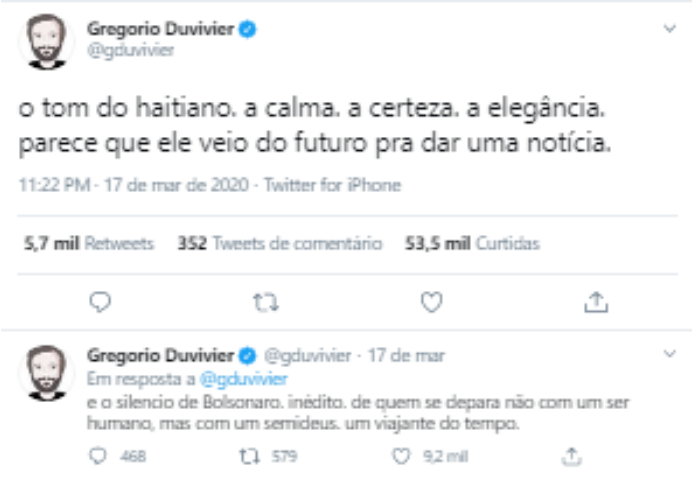

[the Haitian man's tone of voice. his calmness. his assertiveness. his elegance. it looks like he came from the future to break a piece of news.]

6 mil Retweets. 55 mil likes

[and Bolsonaro's silence. unprecedented. it's the silence of someone who faces not a human being but a demigod. a time traveler.]

Duvivier's first post shows an interesting construction through the use of a string of words/expressions-like-sentences that resemble lines of poetry. Each part of the string focuses on one of the Man's characteristics and ends with a period thus calling for a slow, paused reading of the post. Besides the emphasis given by the use of the prosodic resource, there is also an emphasis on the Man's qualities. In our view, this construction sounds like an invitation for followers to engage in the uniqueness of the scene described. In the word-like-sentences, there are reference and predication cues - "tone of voice", "assertiveness", "calmness", "elegance" that provide a detailed characterization of the Man's praxis.

Duvivier's second post is similarly constructed. With a focus on Bolsonaro's silence as something "unprecedented" (in the president's ways of acting and behaving), it suggests a contrast to the Man and indirectly helps to create a scale of comparison.

Used to the President's habitual high pitch of voice, aggressiveness, and discourteousness, both Duvivier and some of his followers make evident the two opposing frames of pragmatics, that of the protagonist and that of the antagonist in the scene. Bolsonaro's "pragmatics of chaos" is thus confronted with what we have named 'pragmatics of resistance'. Below are the replies (reentextualizations) we have chosen to analyze. 
R. B. March 17. In reply to@gduvivier

Um verdadeiro cavalheiro. Bozo ficou esperando um palavrão pra entrar num terreno que ele domina e virar um bate boca, mas ele não veio. O que veio foram palavras duras num tom profético.

[A real gentleman. In a field he masters, Bozo was waiting for a swear word, to enter in a quarrel, but there was none. What came out were hard words in a prophetic tone.]

\section{P. L. March 17. In reply to@gduvivier}

Me chamou atenção a calma do Bozo que geralmente é agressivo. (...) Ele sabia que o Haitiano falava a verdade.

[It called my attention Bozo's coolness. He’s usually aggressive. He knew the Haitian man was telling the truth.]

\section{B. March 17. In reply to@gduvivier}

Achei uma das cenas mais estranhas que eu já vi. Dá a impressão de ser até uma entidade e o Bolsonaro não reage como é de costume dele. Muito estranho! Será que alguém já achou este baitiano?

[It is one of the strangest scenes I have ever seen. It gives the impression the Haitian is a supernatural being and Bolsonaro does not react as he usually does. Very strange! Has someone actually seen this Haitian man?]

\section{H. March 18. In reply to@gduvivier}

Acho q nunca ninguém ousou falar c ele daquele jeito, olhando no olho, sem berrar ou ser submisso, falando verdades tranquilamente! Isso deve tê-lo assustado tanto, ainda + vindo de 1 negro, q ele tanto despreza! O combo de maravilhas nesse vídeo dá vontade de ver em loop eterno!

[I guess nobody ever dared to talk to him that way, looking at him in the eye, no yelling [involved], without being subservient, telling truths in an assertive and unruffled tone! This must have frightened him, more so as it came from a black person, people he despises! The combo of beautiful things in this video makes one wish to see it as an eternal [continued] loop!]

Note that the indirect scalar comparison between the performance of the President and the Man as a common person is now made explicit in the replies written by Duvivier's followers. As put forward by R.B., P.L., and H., the "field he [the President] masters" is that of "swear word[s]", "quarrel[s]", "aggressive[ness], and "yell[ing]". These cues reference, predicate, and evaluate the President's praxis.

Another point to be picked up in Duvivier's second post and also in the replies opposes one's knowledge to the numbness of the other in face of an announced 'truth'. In the meta-reflection on the Man's praxis, Duvivier and his followers narrate and position the Man as someone who is absolutely 'sure' about what he says, as someone who has come to "break some news" with some "hard words" (R.B.) "telling the truth calmly" (H.). Bolsonaro and his fans' astonishment at the Man's words may be summed up in the comment made by M.B.: "It is one of the strangest scenes I have ever seen. It gives the impression that the Haitian is a supernatural being and Bolsonaro does not react as he usually does. Very strange! Has someone actually seen this Haitian man?" 
In the last reply of the sequence above, $\mathrm{H}$. mobilizes two negative words "never" and "nobody" - and ends up with a strategic absolutization of the migrant's act of courage. This lexical choice ("nobody") combined with the verb "dare"/"dared" - which refers to transgression - helps to build the Man's image as someone who is exceedingly courageous. N.'s comment about such courage is built through metaphors constituted by two hyperboles: "The combo of beautiful things in this video makes one wish to see it as an eternal [continued] loop". These exaggerated images highlight the importance of the scene narrated as something to be remembered, as indicated by N.'s desire to watch it eternally.

In addition to Duvivier's Tweet (and replies) just presented, we have also found a materialization of the Man's image as a superior being in a cartoon by Allison Affonso ${ }^{10}$. In contact with the cartoonist, we had the information that its first publication was in the artist's Instagram account ${ }^{11}$ on March 17/2020. We also learned that the cartoon was then reposted on several social media as well as in blogs and newspapers. Allison said he decided to name his cartoon "O Gigante Haitiano [the Haitian Giant] because of the grandeur and determination of the Man's announcement in a moment when numerous Brazilian voices were silent". It should be pointed out that Affonso's reflection matches with the first post of Boulos' Tweet 1: "A Haitian has said to Bolsonaro what millions of Brazilians would like to have said". In both lines of thought, there is a metonymic scale that projects an individual act to the desired action of many.

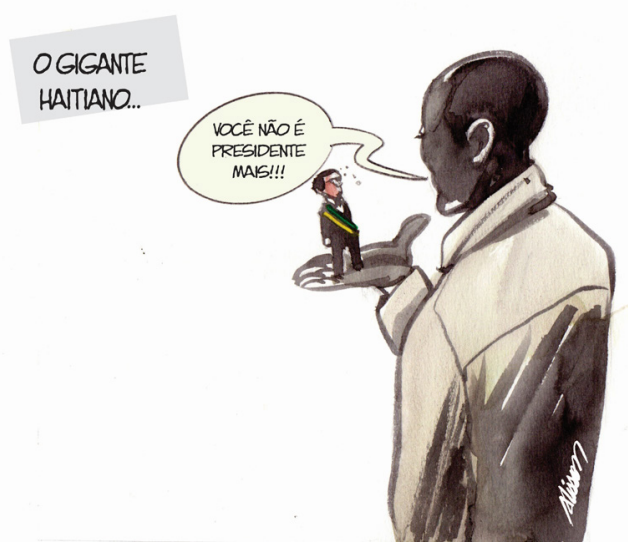

10. We are thankful to @affonso.allison, an award-winning illustrator/graphic artist and cartoonist, for the kind and prompt permission to use the cartoon entitled $\mathrm{O}$ Gigante Haitiano... and also for making available the high-resolution version of the image.

11. https://www.instagram.com/p/B91bgo5gXSq/?igshid=1dm39ydbfyp6h (Accessed 13 September 2020). 
In the cartoon, the giant Man is shown with his back to the audience, as it is in the video scene, and the President is shown as being reduced to a very small size to fit on the former's palm. It is relevant to indicate that the Brazilian Portuguese expression "ter alguém na palma da mão" [to have someone on the palm of one's hand] means "to be the absolute master of someone or some situation; to dominate" (Dicionário Houaiss, 2001, p. 2111). And the Man, says to the President: "Você não é presidente mais!!!" [You're not president anymore!!!]. The President, besides the small size, is portrayed as being flabbergasted, as shown by a semiotic resource: the tiny little dots in front of his face. Spoken by a figure placed on a disproportionately superior scale (both in height and grandeur), the direct and assertive words dazzle the interlocutor.

Interestingly, in the sequence of replies to Duvivier's Tweet, R.B. has the same perception as the one presented by the cartoonist. R.B. also emphasizes the gigantism of the Man's positioning regarding the President, in this case, by focusing on a moral stature comparison:

\section{R. B. March 18 In reply to @gduvivier}

Estatura moral completamente distinta. $O$ maior fala, o menor se cala.

[Very distinct moral stature: the higher moral stature speaks, the lower stature shuts up.]

In the evaluative indices mobilized to refer to the two men in the scene - and, consequently, to their opposing frames of pragmatics: R.B. uses the noun "stature" to allude to the Man, identifying him as having "the higher moral stature" "very distinct" from the other, referenced as "the lower stature". What we have here are two scales of comparison that help to understand that for the latter (the President), nothing more is left besides "shutting up". The figure of speech present in this characterization, an antithesis - higher/lower and speaks/shuts up - strongly reinforces the gigantism of the Man's action.

In the following group of replies to Duvivier's Tweet, another reference and predication that emerge is the Man being described as someone who is "not a human being but a demigod", a "time traveler" who "came from the future" "to break a piece of news". These images provide support for the evaluation of his act of courage as something out of the natural, belonging to the metaphysical realm.

H. S.17 de mar. In reply to@gduvivier

Ele veio do futuro. Se chama afrofuturismo, um modo de pensar futuros possíveis, longe da alienação do narci [si] smo branco. Fanon's feeling

[He's come back from the future. It's called Afrofuturism, a way of thinking about a possible future, away from the alienation of white narcissism. Fanon's feelings.] 
D. R. March 17. In reply to@gduvivier

Não consegui entender até agora por que o Bozo parou pra escutar ele. Como ele é beligerante, nunca escuta ninguém, parece mesmo que o baitiano acabou de sair de uma fenda no tempo-espaço.

[I can't understand why Bozo stopped to hear him. As he has a belligerent nature, he never listens to anybody. It really looks like the Haitian has just come out of a SpaceTime cleft.]

M. March 18. In reply to@gduviviere@L.A.

Sim, acho que ele foi usado por algo superior, porque por aqui estava faltando coragem. Hoje, todos estão dizendo: \#Bolsonaroacabou!

[Yes, I think he was used by some superior being because, over here, there was a lack of courage. Today everybody is saying: \#Bolsonaroacabou! [\#Bolsonaroisover]

N. R. March 17. In reply to @gduvivier

Imprensa nenhuma foi atrás desse herói pra saber o motivo dele está ali frente a frente ao satanás desafiando ele?

[Hasn't any news reporter gone after this hero to find out the reason he was there face to face with that devil, challenging him?]

L. R.17 de mar. In reply to@gduvivier

Não acreditei no que vi... Bolsonaro nem conseguiu responder à aquele anjo

[I don't believe what I have seen... Bolsonaro couldn't even reply to that angel]

Reentextualizing Duvivier and followers' comments about the protagonist being someone who had come from the future, in the first reply of the sequence above, H.S. names the Man's praxis as "Afrofuturism". To elaborate his idea, H.S. mentions Frantz Fanon ("Fanon's feelings) thus mobilizing a citation of autbority and suggesting that the Man is scaled up from being a stranger from any walk of life to being placed on an academic scale of a great Black intellectual. In our interpretation, this upscaling helps to evaluate the Man's discursive performance as sound and credit-worthy. In addition, H.S.'s use of the lexical items "alienation" and "white narcissism" helps to refer and predicate Fanon's theorization as anticolonialist. In H.S.'s reading of the scene, the cleft open in SpaceTime brings together someone that somehow reentextualizes Fanon's anticolonial Black positioning, incorporating the author's epistemological courage thus voiced as someone who can inspire a reaction to the present time and the construction of a future.

The other replies in this sequence also explore the image of a cleft in SpaceTime through which the Man would have come "from the future". This time, however, he is shown as 'some superior being', 'a hero', 'an angel'. Two scales are now present: a real scale and a metaphysical one. In their confrontation, once more, the protagonist's resistance model looms in stark contrast with the antagonist's. In sum, these replies from Duvivier's followers signal that a "special" being was needed to confront the politics of indifference practiced by the President. 
Keeping in mind that the Man was not seen again, the metaphysical character of the event is reinforced. As N.R. points out in a question, in the sequence of replies above, nothing was known about the whereabouts of the migrant, or about his identity, and there were no records of interviews or any other type of information about him in the mainstream media. The protagonist's lack of materiality thus reinforces his supposedly super-human power. In fact, only in May did we find a piece of news ${ }^{12}$ saying that the Man had not been seen or found after the event. Moreover, the mainstream press has somehow ignored this event, generally referring to an alleged ${ }^{13}$ video or to a video that was allegedly recorded. Had the Press or televised Media been present at the event or found a way to check this fact, it, certainly, would have been broadcast in TV news programs and mainstream newspapers.

The Man, entextualized as a superior being, travels to other instances of communicative practices that creatively use other semiotic resources, as the Instagram account @acabou_posters ${ }^{14}$ [itsover_posters], opened by Alexandre Kazuo $\mathrm{Kubo}^{15}$, an ad designer and art director.
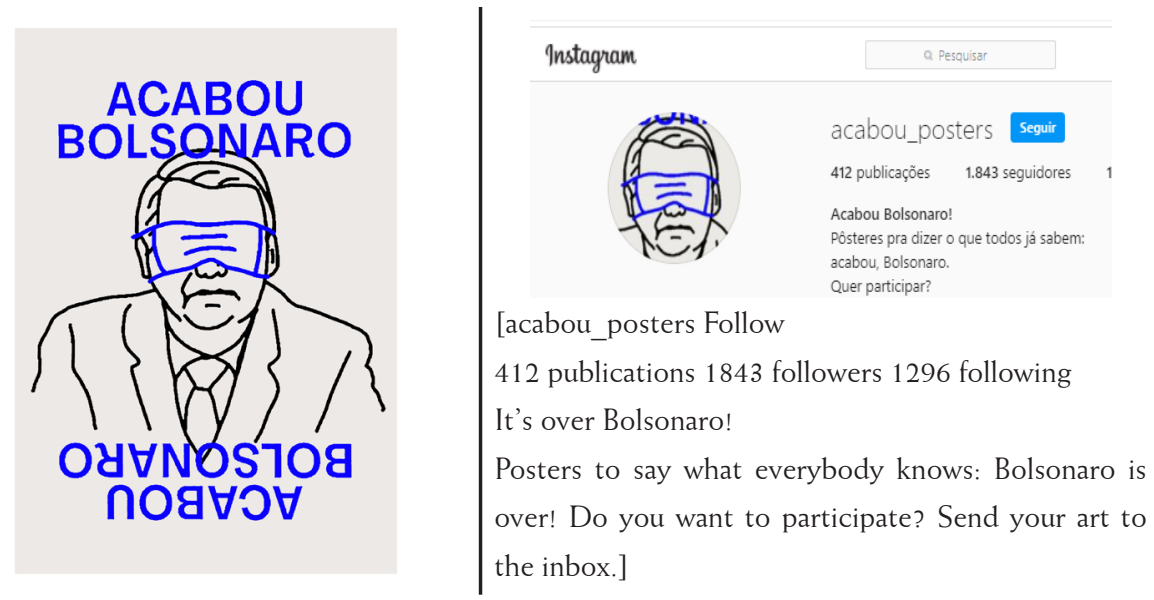

As Kubo told us in an Instagram message exchange, he had the idea to open the account soon after having seen the video on social media. The first publications

12. https://www1.folha.uol.com.br/colunas/painel/2020/05/identidade-de-haitiano-que-disse-a-bolsonaroque-seu-governo-havia-acabado-e-um-misterio.shtml (Accessed 01 October 2020).

13. See, for example, https://www1.folha.uol.com.br/equilibrioesaude/2020/03/voce-nao-e-presidentemais-diz-haitiano-a-bolsonaro-apos-crise-do-coronavirus.shtml (Accessed 13 September 2020).

14.https://www.instagram.com/acabou_posters/ (Accessed 16 September 2020).

15. We are indebted to the art designer who kindly authorized the use of the poster that illustrates his account @acabou_posters on Instagram and also made available its high-resolution version. 
in his account were posters made by invited friends who are artists and ad designers. Then many other artists, unknown to him, sent other material for publication. Kubo said he does not consider his account as part of activism, however, he acknowledges that the moment "requests that everybody takes some action".

Below is one of the posters published in@acabou_posters. Created by the graphic artist Daniel Thomer ${ }^{16}$, it has a graphic representation of an angel, a figure already mentioned by L.R., in the last reply to Duvivier's Tweet.

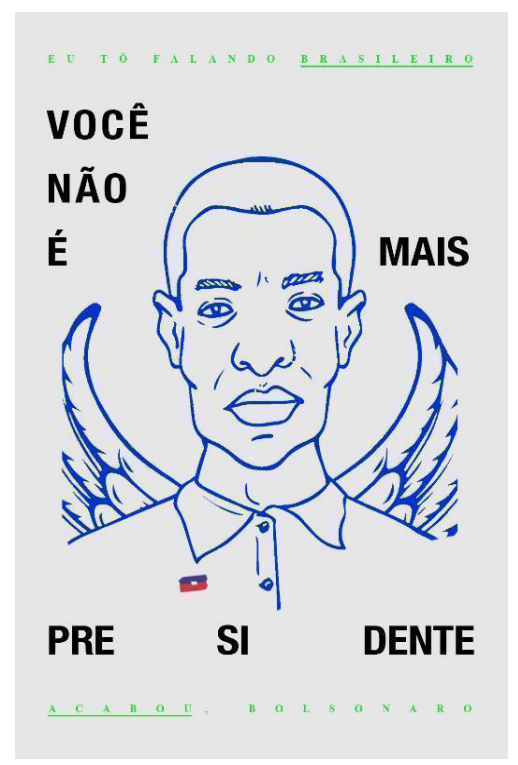

5 abril 2020 - acabou posters @danithomer \#acaboubolsonaro \#acabou posters

Besides the wings, three other indices are highlighted in the poster: the Haitian flag, a human (physical) face, and the sentence "Eu tô falando brasileiro" ["I'm speaking Brazilian"], indicating his nationality, a face not shown in the video, and his performance as a Haitian-Brazilian, respectively. These three indices position the Man as having particular identities, and go against the fact that his identity and whereabouts are unknown, as already mentioned.

The statement "I'm speaking Brazilian" on the poster is a reentextualization of the Man's words. This statement backed up by "I'm now Brazilian" present in the

16. We thank the Brazilian graphic artist Daniel Thomer (@danithomer - https://danielthomer.com/) for authorizing the use of this poster in this article and for making available its high-resolution version. https://www.instagram.com/p/B-njhggnWFs/? igshid=1ou38obqhydc9 (Accessed 16 September 2020). 
video, may be seen as an index that the Man acknowledges himself as territorialized, as someone who now belongs to the country he has chosen. The predication "Brazilian" besides referring to nationality has also been appropriated by the Man to name the language of the country. What is highlighted on the poster is, on the one hand, the Man's physical representation as if he were facing the President. On the other hand, under the spotlight as well, is a sentence that has also become a hashtag: "You are not president anymore!". Thus, the artist's entextualization, besides bringing one of the Man's impacting phrases to the poster, also creates a face for him, a serene face of confrontation seen here as part of his praxis. As a final thought, there is a scalar alignment to be pointed out: the Man, although referred to as a migrant in the (mainstream and social) media may be a documented Brazilian citizen, positioning himself on the same scale of nationals, addressing them (us) and summoning them (us) for another frame of pragmatics: that of resistance.

The threads of the viral hashtag and of the Man's performance running in the entextualizations on social media and in art activism have displayed a meta-reflexive fabric. In these entextualizations, we have come across some semiotic cues that have helped us to draft our pragmatics of resistance, i.e., our understanding of the resilience and potential power of transformation to face a bleak period in Brazilian society. To carry out the draft, we continue our dialogue with Silva's (2020) "pragmatics of chaos" - i.e., the author's understanding of the contemporary Brazilian President's way of governance. We take pragmatics of resistance as a mechanism to confront what, in this article, we pointed out as a 'politics of indifference' concerning the vulnerable Other. We view this politics, that includes the dismantling of the health and educational systems and other public services essential for vulnerable groups, the adoption of a reductionist migratory policy, and the denial of human rights on all levels, as part of the "pragmatics of chaos". Whereas this pragmatics is guided by the erasure of the Other as a "method of producing permanent sentiment of agitation, murk, and discontent in political audiences" (SILVA, 2020, p. 507), the pragmatics of resistance emerges as a reaction mechanism to face these erasures. Characterized by the appropriation of the problem of the Other, it acts meta-reflexively through a serene, transparent and direct confrontation towards indifference. As a counterpart to the feeling of discontentment and gloominess that the chaos stirs, it fosters Hope, projecting the individual as responsible for the collective.

\section{CLOSING REMARKS}

In this final section, before closing the article, we address the scalar dynamics that emerge from the data analysis regarding the two aims proposed for this article: 
(i) the configuration of the Man's discursive performance together with the (re) entextualization of his words on social media, and (ii) the ways it has impacted virtual collective agency in times of a pandemic. Assuming that scalar dynamics cannot be viewed linearly, we try to show the intertwinings appearing in the weaving of the threads of the hashtag in its (re)entextualizations.

Regarding the Man's discursive performance, its entextualization begins in the Twitter accounts, first with one of the account owners' identification with the Man ("My soul has been redeemed"). The sentence is followed by a scalar projection of the Man's performance to the desired action of a great part of the population. Second, on a scale of comparison/contrast with the President, in the other Twitter account, as well as in the cartoon, and the art poster, there is a description that associates the Man to a human and 'real' model of education, gentleness, elegance, assertiveness. In a scalar transposition, this description leaves behind the 'real' world when the model reaches a status of superiority ["The Haitian Giant"] and perfection [an Angel]. The Man is then positioned as a hero and an angel on a metaphysical plane, only accessed through the SpaceTime cleft where he might have come from.

Concerning the hashtag itself, its threads of entextualization may be seen in a scalar progression. First, there is a scalar movement that goes from a local to a national sphere, that is, the video recording made in a controlled environment with access granted to few people scales up to a virtual open space with its publication on YouTube and its sharing on social media (Twitter and Instagram). Second, there is a series of scalar transitions within one social media (Twitter), beginning with the Man's words - "Acabou Bolsonaro"- as a soundbite that is used as a caption for the video recorded episode when it is reposted on Twitter. The soundbite also appears as a tag in one of the Twitter accounts. Then as an actual hashtag, it is used in the Twitter accounts of two public figures, a politician and a digital influencer, each one of them with more than one million followers. In the politician's account, the hashtag surfaces in two invitation posters. It also becomes a political slogan and is used as a stamp to endorse invitations for protests. On March 17, the day after the event, the hashtag reaches first place as a trending topic on Twitter. As a political slogan, during the pandemic, it is also shouted from balconies and windows in the pot-banging protests that lasted a fortnight. Moreover, this political slogan, in yet another scalar transposition, also reaches the façades of buildings in laser projections in some of these protests, mainly in big cities. Furthermore, in the digital influencer's Twitter account, the Man's words and performance become the focus of reflexive tweets and replies. Finally, the performance and hashtag, in yet 
another scalar transposition, leave a virtual worldly life to enter virtual art design on Instagram, traveling through different semiotic resources, genres, and (social) media. They inspire art activism in two accounts, one of them partially named after the soundbite: Acabou_Posters. In other words, the scalar dynamics is not linear, it is a complex dance from the so-called real world to the virtual world also crossing over to one type of art world. It travels from Twitter accounts with millions of followers to Instagram art designer' accounts with only thousands of them. As part of the dynamics, the hashtag itself encapsulates the Man's pragmatics of resistance.

As to the reverberation of the episode, its (re)entextualizations can also be shown in scalar dynamics, as qualitatively impacting the virtual collective agency. The (re)entextualized episode, as focus of metapragmatic reflection, triggers virtual calls for protests and the actual protests themselves. Besides, it also impacts individual and collective artistic activism. There is a scalar progression taking the individual episode to virtual collective action and a scalar transposition to a general art dimension that is unfolded in artistic expression for (individual or collective) activism of resistance.

The episode is now in the past. The unknown Man, whose challenging announcement has not materialized, seems to have been forgotten, but the hashtag (with its variants: soundbite and political slogan) continues to be used on Twitter and Instagram. On Twitter, it is taken up each time a new political fact arises, be it directly or indirectly related to the President. It is also boosted when some governmental acts or announcements offend any of the spectra of human rights or environmental protection. On Instagram, the account@acabou_posters ${ }^{17}$ also continues with publications as illustrated by the art activism of Padilha ${ }^{18}$ on April 1, 2020, and of Kubo ${ }^{19}$ (the account owner) on October 1, 2020.

17. See the project@acabou_posters in Kazuo Kubo's portfolio: https://www.kazuokubo.com.br/ bolsonaro (Accessed 2 October 2020).

18. Our thanks to the artist for letting us reproduce his work here. See also: https://paadilhaa. myportfolio.com (Accessed 10 September 2020).

19. We are indebted to the artist again for making available the high-resolution image available. The poster was specially made to represent his work in an international festival. 


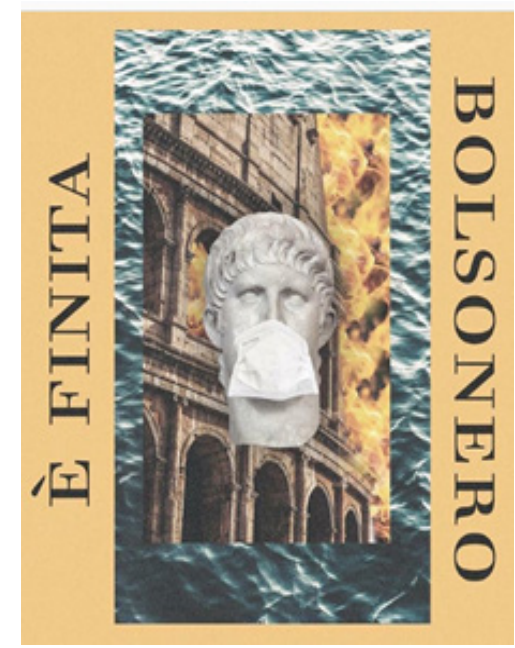

acabou_posters. April 1.2020. @padilhath

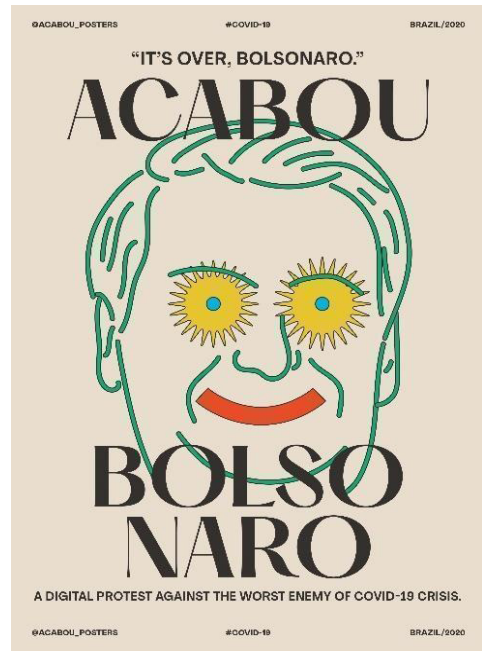

acabou_posters. October 1.2020. @

kazuokubo

In October 2020, the COVID-19 pandemic had surpassed 159,000 deaths with cases and hospitalizations rising. This longstanding pandemic seems to hold a metaphor for the feeling of never-ending that encompasses the multiple crises being faced by Brazilian society. In this scenario, by opposing the two frames of pragmatics - chaos, and resistance - we highlight the perspective of Hope that emanates from the reflexivity and meta-reflexivity on the episode of agency, resistance, and resilience featured by the migrant of Haitian origin. This resisting strategy has made visible the occurrence of agency in a space where there appeared to be no active response in the face of political chaos and democratic deterioration.

\section{REFERENCES}

ANDREOTTI, V. (2018). Educação para expansão de horizontes, saberes, vivências, afetos, sensibilidades e possibilidades de (co)existência. Sinergias, n. ${ }^{\circ}$ 6, s/p. Available at: http://www.sinergiased.org/index.php/revista/item/136 (Accessed 29 July 2020).

BAENINGER, R. A.; PERES, R. G. (2017). Migração de crise: a imigração haitiana para o Brasil. Revista Brasileira de Estudos da População. Belo Horizonte, v. 34, n. 1, p. 119-143. Disponível em: http://www.scielo.br/ scielo.php?script= sci_arttext \&pid= S0102$30982017000100119 \& \operatorname{lng}=$ pt\&nrm $=$ iso (Accessed 30 July 2020). 
BAUMAN, R.; BRIGGS, C. (1990). Poetics and performance as critical perspectives on language and social life. Annual Review of Antbropology, v. 19, pp. 59-88.

BHABHA, H. K. (2007/1998). O local da cultura. Belo Horizonte: Editora UFM.

BIZON, A. C. C. (2013). Narrando o exame Celpe-Bras e o convênio PEC-G: a construção de territorialidades em tempos de internacionalização. Tese (Doutorado em Linguística Aplicada) - Instituto de Estudos da Linguagem, Unicamp, Campinas-SP.

BLOMMAERT, J. (2005) Discourse - Key Topics in Sociolinguistics. New York: Cambridge University Press.

BLOMMAERT, J.; WESTINEN, E.; LEPPÄNEN, S. (2015) Further notes on sociolinguistic scales. Intercultural Pragmatics, 12/1: 119-127.

CARR, E.S.; LEMPERT, M. (2016) Scale: discourse and dimensions of social life. Oakland: University of California Press.

Dicionário Houaiss da Língua Portuguesa [Houaiss Dictionary of Portuguese Language] (2001), Rio de Janeiro: Editora Objetiva.

GONZALEZ, C.; MOITA LOPES, L. P. (2018). Metapragmatic reflexivity about Almodóvar's cinema on an online interaction: indexicality, scales and entextualization. Trab. Ling. Aplic., Campinas, n(57.2): 1102-1136, mai./ago.

MAGALHÃES, L. F.; VON ZUBEN, C.; PARISE, P.; DEMÉTRIO, N.; DOMENICONI, J. (Orgs.) (2020) Migrações internacionais e a pandemia de Covid-19, Campinas-SP: Núcleo de Estudos de População "Elza Berquó", 2020, p. 584-608.

MARANGONI, A. \#AcabouBolsonaro e \#RespeiteOPresidente lideram no Twitter - Hashtags foram usadas por apoiadores e críticos ao presidente". Revista Oeste, 18 Março 2020. Available at: https://revistaoeste.com/acaboubolsonaro-erespeiteopresidente-lideram-no-twitter/ (Accessed 30 August 2020).

RAJAGOPALAN, K. (2014) Da arrogância cartesiana à "nova pragmática" (Prefácio). In: SILVA, D.; FERREIRA, D. \& ALENCAR, C. (Orgs.), Nova pragmática: Modos de fazer. São Paulo: Cortez.

SANTOS, B. S. (2002). Para uma sociologia das ausências e uma sociologia das emergências. Revista Crítica das Ciências Sociais, 63, Out., pp. 237-280. Available at: http://www. boaventuradesousasantos.pt/media/pdfs/Sociologia_das_ausencias_RCCS63.PDF (Accessed 01 June 2020). 
SANTOS, B. S. (2020). A cruel pedagogia do virus [The cruel pedagogy of the virus]. Coimbra: Almedina. Available at: https://www.cpalsocial.org/documentos/927.pdf (Accessed 25 April 2020).

SIGNORINI, I. (2008) Metapragmáticas da língua em uso: Unidades e níveis de análise. In: SIGNORINI, I. (Org.) Situar a Linguagem. São Paulo: Parábola, p.117-148.

SILVA, D. N. e. (2014). O texto entre a entextualização e a etnografia: um programa jornalístico sobre belezas subalternas e suas múltiplas recontextualizações. Linguagem em (Dis)curso - LemD, Tubarão, SC, v. 14, n. 1, p. 67-84, jan./abr. 2014.

SILVA, D. N. e. (2020). The Pragmatics of Chaos: Parsing Bolsonaro's Undemocratic Language. Trabalbos em Linguística Aplicada, 59(1), 507-537. Available at: https:// periodicos.sbu.unicamp.br/ojs/index.php/tla/article/view/8659107 (Accessed 13 September 2020).

SPIVAK, G. (1994) Can the subaltern speak? In: WILLIAMS, P.; CHRISMAN, L. (Eds.) Colonial Discourse and Post-Colonial Theory. New York: Columbia University Press: 66111.

WORTHAM, S. (2001) Narratives in Action. A strategy for research and analysis. New York/ London: Teachers College; Columbia University.

Recebido: 10/12/2020

Aceito: 7/1/2021

Publicado: 18/1/2021 